\title{
A Review on COVID-19 Outbreak: An Unprecedented Threat to the Globe
}

\author{
Yamini Kanipakam ${ }^{1}$, Vezhavendhan Nagaraja ${ }^{2}$, Bala Maddileti Gandla ${ }^{3}$, Santha Devy Arumugam ${ }^{4}$
}

\begin{abstract}
The coronavirus outbreak in December 2019 has added renewed interest in bygone micro enemy and upraise questions about the ability of current protective measures in our healthcare system to handle this threat. It is a known fact that coronaviruses to cause respiratory infections in humans for over six decades, but their pandemic potentiality has been addressing for the last few years. Coronavirus disease-19 (COVID-19) has caused so much concern around the world that the World Health Organization (WHO) on January 30, 2020, proclaimed it as a world health emergency, and on March 11, 2020, the WHO declared COVID-19 a global-wide pandemic. The ease at which this virus spread caused people to use some precautionary measures such as masks and gloves, resulting in the generation of a large amount of medical waste in the environment. To reduce the spread of the virus, human beings were put on restricted at homes in the name of lockdown. This pandemic has also altered people's lifestyles. This analysis reflects the current state of public health impact; we deal with current information on coronaviruses, including epidemiology, signs and symptoms, disease manifestation, and treatment and prevention strategies.

Keywords: Coronavirus, Epidemic, Global health emergency, Pandemic.

Journal of Scientific Dentistry (2021): 10.5005/jp-journals-10083-0942
\end{abstract}

\section{INTRODUCTION}

Coronavirus disease-19 (COVID-19) pandemic constitutes an unexpected warning to the entire globe which is encountering extensive transmission of the virus for several weeks. In addition, with high associated mortality many countries implementing "stayat-home" policies, physical distancing measures. ${ }^{1}$ Now the entire world is facing the challenge of this new outbreak from an old enemy. This has been considered as the "third major coronavirus outbreak over the past 2 decades" and causing a dramatic collision on human life and as well as world's economy. In the 21st century, this outbreak is the first incident to affect all continents except Antarctica. ${ }^{2}$ In a city named Wuhan of China atypical pneumonitis was reported in late December 2019 which has been linked to an animal market in the same locality. ${ }^{3}$ On January 26 , the causative microorganism of this unusual pneumonia was named COVID-19. ${ }^{4}$ This outbreak is referred to as "severe acute respiratory syndrome coronavirus-2 (SARS-CoV-2) or coronavirus disease-19 (COVID-19)". 5 Because of its very rapid spreading COVID-19 caused varying degrees of health issues in entire China. On January 30, 2020, based on its incidence and prevalence rate, the World Health Organization (WHO) announced a global health emergency. ${ }^{4,6}$ On March 11, 2020, the WHO proclaimed COVID-19 as a worldwide pandemic, as $>118,000$ cases were identified globally. ${ }^{7}$ Coronavirus disease-19 endangering the health and well-being of the vulnerable population and become a global threat. ${ }^{8,9}$

We have tried to encapsulate the epitome of COVID-19, transmission and evaluation, etc. The goal is to amalgamate the knowledge about corona to address the current health emergency. We try to give our best in regard to management, evaluate predict complications and prognosis, and provide opportunities for research in this review.

\section{An Overview of Coronavirus}

Severe acute respiratory syndrome coronavirus-2 related to the family Coronaviridae, order Nidovirales. It is classified into four sub-variants:

\footnotetext{
1,4 Department of Oral and Maxillofacial Pathology and Oral Microbiology, Indira Gandhi Institute of Dental Sciences, Sri Balaji Vidyapeeth, Puducherry, India

${ }^{2}$ Department of Oral Pathology, Indira Gandhi Institute of Dental Sciences, Sri Balaji Vidyapeeth, Puducherry, India

${ }^{3}$ Department of Forensic Medicine and Toxicology, SRM Medical College Hospital and Research Centre, Trichy, Tamil Nadu, India

Corresponding Author: Yamini Kanipakam, Department of Oral and Maxillofacial Pathology and Oral Microbiology, Indira Gandhi Institute of Dental Sciences, Sri Balaji Vidyapeeth, Puducherry, India, Phone: +919444848548, e-mail: dr.mini2711@gmail.com

How to cite this article: Kanipakam Y, Nagaraja V, Gandla BM, Arumugam SD. A Review on COVID-19 Outbreak: An Unprecedented Threat to the Globe. J Sci Dent 2021;11(1):37-41.

Source of support: Nil

Conflict of interest: None
}

human-infecting, animal infecting, gamma, and delta variants. All four variants are single-stranded RNA viruses that infect humans as well as animals. ${ }^{10}$ These viruses contain ranges genomic range from 26 and $32 \mathrm{~kb}$. Nucleocapsid protein, the spike protein, a small membrane protein, and the membrane glycoprotein are the four structural proteins. Severe acute respiratory syndrome coronavirus-2 genome and genome of bat coronavirus are identical. ${ }^{11}$ An average incubation period of coronavirus is $\mathbf{0 - 2 4}$ days. It causes a various range of symptoms that affect the various systems such as the respiratory and gastrointestinal systems. ${ }^{12,13}$ At first in 1966, Tyrell and Bynoe cultured these viruses from common cold patients. Severe acute respiratory syndrome coronavirus- 2 was first isolated in Wuhan city from COVID-19 infected patients and was recognized as a novel coronavirus. ${ }^{14}$ Severe acute respiratory syndrome coronavirus- 2 is a zoonotic virus that can spread among humans via aerosols. The main carrier for humans is the bat. Four different subfamilies were reported to infect humans including alpha, beta, gamma, and delta. ${ }^{15}$ Original 
SARS-CoV originated in another province called Guangdong of China, infected thousands of individuals in 29 countries, and 774 deaths. ${ }^{16}$ In 2012, a novel $\beta$-coronavirus caused Middle Eastern Respiratory Syndrome (MERS-CoV), because of this $>2,494$ individuals infected, and 858 deaths reported across 27 countries in November 2019. ${ }^{17}$ At the time of authoring globally, as of 8:25 am CEST, May 21, 2020, almost $4,864,881$ cases of and 321,818 deaths related to COVID-19, reported to $\mathrm{WHO}^{18}$

\section{Epidemiology of Coronavirus Infections}

Because of the emergence of dangerous strains of coronavirus in recent years, it has triggered more studies on coronavirus mutation and transmission between animals to humans and vice versa. It has got variations in gender, age. Elderly males are more affected by SARS-CoV-2, females, and children aged between 5 years and 14 years are affected by other non-disruptive coronaviruses. ${ }^{19}$ In contrast, SARS-CoV-1 infects more females, and young people, and the death rate at $12 \%$ in old patients. ${ }^{20,21}$ But the MERS coronavirus affects commonly males and middle-aged persons. ${ }^{22}$ Existing data from Wuhan of China showing $68 \%$ of cases are middle-aged males, in those more than half had chronic diseases. ${ }^{23}$ All three viruses such as SARS-CoV-2, COVID-19, and MERS-CoV are most likely to have originated in bats. ${ }^{24,25} \mathrm{~A}$ pandemic can be defined as "the worldwide spread of a new disease." Lack of preexisting immunity is the main reason for this rapid spreading of the coronavirus. ${ }^{5}$ In the year 2009, H1N1 pandemic infected about 140 crore people and caused more than half a million deaths. ${ }^{26}$ The outbreak started as patients presenting with atypical pneumonia in Wuhan City, in late December 2019. ${ }^{27}$ Later within 3 days of duration, the WHO got noted 44 new cases from the same city. Japan and South Korea were the first countries to report cases other than the China. ${ }^{28,29}$ Within 5 days of WHO declaration of this situation as a pandemic, the virus spread to $>140$ countries with 6,606 deaths. ${ }^{30}$ Chinese viral laboratories isolated a strange variant of coronavirus, on January 7 , $2020 .{ }^{31}$ By the end of January 2020, United States, Japan, Thailand, and South Korea reported their first positive cases of COVID-19. ${ }^{27,32}$ The WHO declared a Public Health Emergency of International Concern (PHEIC) on January 30, 2020. ${ }^{33}$ Public Health Emergency of International Concern can be defined as "an extraordinary event which is determined to constitute a public health risk to other States through the international spread of disease and to potentially require a coordinated international response." Also, as per the WHO. ${ }^{34}$ February 10, 2020, almost 910 COVID deaths have been reported from many countries and a major portion from China. ${ }^{35}$ On February 11, 2020, it has been discovered as COVID-19 by WHO. ${ }^{36}$ By March 10,2020, the case rate was escalated $>110,000$ cases in 110 countries. On March 11, 2020, the WHO Director-General announced COVID-19 as a pandemic based on statistics of cases and deaths in 114 countries. $^{37,38}$

\section{TRANSMISSION}

Transmission of this virus is through respiratory droplets in-between persons when SARS-CoV-2 infected patient coughs, spits, or sneezes. Transmission is minimal when people maintain at least $2 \mathrm{~m}$ distance. Transmission can be through aerosols while singing or intubation or the use of nebulizers and the virus can be active in aerosols for $>3$ hours. ${ }^{39,40}$ Even though no confirmation of feco-oral transmission its RNA has detected in serum and stool. Severe acute respiratory syndrome coronavirus-2 may be active for days on persist on plastic, wood, and stainless steel. Transmission through contaminated inanimate have been documented. ${ }^{40-42}$ Pre-symptomatic and asymptomatic people also can spreads the SARS-CoV-2. ${ }^{43}$ Mean basic reproductive number for COVID-19 is defined as "average number of secondary infections produced by a case of an infection in a fully susceptible population - at 3.28, with a median of 2.79". Transmission potential at a given region is called as basic reproduction number ( $\mathrm{R} 0$ ) and transmission potential at a given time is called as effective reproductive number (Re). After implementation of physical distance measures, it is noted that $\mathrm{Re}$ is reduced in all regions of Italy. ${ }^{44}$ More viral load is seen in nasopharyngeal specimens for about a week in mild cases. ${ }^{45,46}$ In severe cases, it reaches peaks in 7-14 days after infection. ${ }^{47}$ The high viral load close to symptom onset suggests that SARS-CoV-2 can be easily transmissible at an early stage of infection and viral RNA has been isolated in other body fluids such as saliva and urine. ${ }^{48,49}$ Severe acute respiratory syndrome coronavirus- 2 virus RNA was detected up to day 21 in ocular fluid. A recent study reported that asymptomatic individuals are dangerous carriers for COVID-19 pandemic spread. ${ }^{50,51}$ Existing studies showed risk of SARS-CoV-2 transmission through blood components is very negligible. ${ }^{52}$

\section{Signs and Symptoms}

As per case-based data to European Surveillance System (TESSy) from countries such as Germany, Portugal, the most commonly reported clinical symptom was fever, cough, throat pain, general weakness, generalized body pains, watery nose, and gastroenteritis in the respective order. But symptoms vary between countries. According to the data collected from the USA, the most common reported symptoms were dry or productive cough with fever or chills and generalized body pains. ${ }^{53}$ Reports from US CDC listed the symptoms such as chills, shaking, headache, and a disturbance in taste or smell. ${ }^{54}$ In a few cases, conjunctivitis is also reported as a symptom. ${ }^{50}$ Few studies reported severe cases presented with thrombosis and purpuric lesions and shortness of breath. ${ }^{55-58}$

\section{Evaluation}

Severe acute respiratory syndrome coronavirus-2 can be diagnosed by polymerase chain reaction (PCR) assay. ${ }^{59}$ Initial symptomatic period, the sensitivity of PCR testing swabs from nose and pharynx is high, but with less specificity in terms of false-negative. Test to be repeated in case of false negative is suspected if that person belongs to active community transmission area. ${ }^{60}$ The type of sample mostly used PCR assays across the world is testing nasopharyngeal swabs. Sputum and lower respiratory tract secretions also can be tested. Sputum samples will be easier and sensitive. ${ }^{61}$ It is contraindicated because of the possibility of aerosol infection, in one study, test sensitivity of oropharyngeal swabs was low especially in the late disease course. ${ }^{62}$ If a nasopharyngeal swab could not be taken from a patient alternative sample can be collected from the oropharynx. ${ }^{63}$ The Food and Drug Administration (FDA) recently recognized on-site self-collection of nasopharynx secretion from anterior nares as an acceptable method of collection. ${ }^{64}$ Patients with mild manifestations are not mandatory to be investigated but there may be a danger of clinical deterioration. ${ }^{65,66}$ Conditions such as respiratory rate $\geq 30$ breaths per minute, $\mathrm{SPO}_{2} \leq 93 \%$, etc., are considered as severe illness. ${ }^{67}$ Few other tests include complete blood investigations, chest computed tomographic (CT) scan coagulation studies estimation of D-dimer, CR protein, and 
procalcitonin levels. The prognostic value and clinical utility of the results of these and other tests remain uncertain. Mass screening procedures have shown that the spectrum of manifestations with this virus appears to be wide, with a range of asymptomatic infection to death. ${ }^{6,68}$ Radiographic findings revealed that patients had abnormalities on a chest CT scan.

\section{Treatment of Coronavirus-associated Diseases}

Supportive measures and isolation are enough in mild cases. Moderate and severe cases are used to monitor the hospital. As of now, there are no approved treatments for COVID-19. Hydroxychloroquine, chloroquine, and azithromycin have appeared in vitro activity probably could be due to antagonizing endosomal transport. ${ }^{69,70}$ There are many studies on ifs and buts in using hydroxychloroquine combined with azithromycin, lopinavirritonavir, or any other HIV-1 protease inhibitor. Remdesivir shown its activity in several animal trials. ${ }^{71-74}$ Several immunomodulating therapies are under investigation, non-steroidal anti-inflammatory drugs. Convalescent plasma therapy also got less clinical data.

Social factors which drive the catching of virus are densely packed people in urban areas especially in slums, big household, dissimilar levels of social distancing, communal gatherings, mass prayers, gatherings in marriages, and other family functions. Medical and health factors such as diabetes, carcinomas, cardiorespiratory diseases, vascular diseases, and immune-compromised conditions, and both extremities of age are more prone to get an infection. ${ }^{75-77}$ World Health Organization has alerted people to the dangers of smoking on the lungs and the risk of COVID-19.

\section{Prevention Strategies}

Healthcare workers who are more prone to get infection must be protected. By reducing the number of healthcare workers and allotment of duties on a rotation basis can minimize the possibility of continuous exposure of health staff to infected persons and maintaining hygiene in the surroundings are critical by using personal protective equipment (PPE) such as goggles/a face shield, mouth mask, an isolation gown and gloves for the routine care of patients with COVID-19 is mandatory as per the WHO guidelines. ${ }^{78-81}$ Instead of a face mask, the CDC prefers the use of an "N95 filtering facepiece respirator, a powered air-purifying respirator [PAPR] unit, or a contained air-purifying respirator [CAPR]" as an acceptable alternative due to the shortage of supply. ${ }^{82}$ By supporting universal droplet-contact precautions, we can reduce the transmission from asymptomatic positive patients. ${ }^{39,83-86}$ Strategies for prevention and control to be needed for people living in congregate settings, dormitories, jails, prisons, etc.

\section{Rights and Legal Obligations of Physician's during Pandemics}

Medical practitioners should not deny attending the duty for fear of getting infected themselves during an outbreak and should notify communicable disease to the constituted health authorities. Doctors should enlighten the public regarding measures for the prevention and control of communicable diseases and quarantine regulations during an outbreak. Though practitioner has the right to choose patients, no physician shall arbitrarily refuse to treat the patient. Physicians have a legal obligation to treat emergencies as per their capacity even if it is not within the range of experience. ${ }^{87}$ If the doctor has any high-risk factors or inaccessibility of PPE, should make alternative arrangements for his/her personal and as well as patient care or has to inform the government authority and take permission for not to attend the duty temporarily.

\section{Conclusion}

The novel coronavirus originated from the animal market at Wuhan city in China and rapidly spread across the world. Even though of SARS-CoV-2 source from animal origin is not confirmed, existing studies suggested that bats are the key reservoir. There are many variants of coronaviruses. Only seven variants of those infect human beings and four of them cause signs of the not unusual cold. SARS, a beta coronavirus appeared in 2002 and turned into managed especially by way of aggressive public health measures. MERS come out in 2012, nonetheless exists in camels, and might infect human beings who have got exposed to them. The new coronavirus at first detected in Wuhan city of China in December 2019, but now it has got hooked up itself across the world and turned out pandemic. On March 11, 2020, because it unfolded the disorder out of doors of China, the WHO declared the corona epidemic as a global pandemic. The manifestations of SARS-CoV-2 precipitated corona are a bit much like influenza and other seasonal allergies and increased body temperature which can be detected via thermal screening; hence, the individual turns into suspected. Therefore, an accurate and speedy diagnostic procedure to be needed as PCR is a costly and time taking process. Health officials are working to contain the unfold of the virus through public fitness measures together with social distancing, contact tracing, trying out, quarantines, and journey restrictions. Until now, no promising medical remedies or prevention techniques have been advanced in opposition to human coronaviruses. Various broad-spectrum antivirals previously used toward influenza, SARS, and MERS coronaviruses were evaluated both alone or in mixtures to deal with COVID-19 sufferers, mice models, and scientific isolates. Scientists are trying to find cures for the disease and create a vaccine. There needs to be strict law enforcement on utilizing wild animals and birds as a source of food. The only way that we can get prevented from this rampage is effective vaccination.

\section{References}

1. Assessment RR, Coronavirus disease 2019 (COVID-19) in the EU/EEA and the UK-ninth update.

2. Docea AO, Tsatsakis A, Albulescu D, Cristea O, Zlatian O, Vinceti M, et al. A new threat from an old enemy: re-emergence of coronavirus. Int J Mole Med 2020;45(6):1631-1643. DOI: 10.3892/ijmm.2020.4555

3. Xu Z, Shi L, Wang Y, Zhang J, Huang L, Zhang C, et al. Pathological findings of COVID-19 associated with acute respiratory distress syndrome. Lancet Respirat Med 2020;8(4):420-422. DOI: 10.1016/ S2213-2600(20)30076-X.

4. Saadat S, Rawtani D, Hussain CM. Environmental perspective of COVID-19. Sci Total Environ 2020. 138870. DOI: 10.1016/j. scitotenv.2020.138870.

5. Vannabouathong C, Devji T, Ekhtiari S, Chang Y, Phillips SA, Zhu M, et al. Novel coronavirus COVID-19: current evidence and evolving strategies. J Bone Joint Surg Am Vol 2020;102(9):734. DOI: 10.2106/ JBJS.20.00396

6. Guan WJ, Ni ZY, Hu Y, Liang WH, Ou CQ, He JX, et al. Clinical characteristics of coronavirus disease 2019 in China. N Engl J Med 2020;382(18):1708-1720. DOI: 10.1056/NEJMoa2002032.

7. World Health Organization (WHO), Coronavirus disease 2019 (COVID19) situation report -51.2020 .

8. Mao R, Liang J, Shen J, Ghosh S, Zhu LR, Yang H. Implications of COVID-19 for patients with pre-existing digestive diseases. Lancet 
Gastroenterol Hepatol 2020;5(5):425-427. DOI: 10.1016/S24681253(20)30076-5.

9. Tsai J, Wilson M. COVID-19: a potential public health problem for homeless populations. Lancet Public Health 2020;5(4):e186-e187. DOI: 10.1016/S2468-2667(20)30053-0.

10. Kooraki S, Hosseiny M, Myers L, Gholamrezanezhad A. Coronavirus (COVID-19) outbreak: what the department of radiology should know. J Am Coll Radiol 2020;17(4):447-451. DOI: 10.1016/j.jacr.2020. 02.008 .

11. Kucharski AJ, Russell TW, Diamond C, Liu Y, Edmunds J, Funk S, et al. Early dynamics of transmission and control of COVID-19: a mathematical modelling study. Lancet Infect Dis 2020;20(5):553-558. DOI: 10.1016/S1473-3099(20)30144-4.

12. Li M, Lei P, Zeng B, Li Z, Yu P, Fan B, et al. Coronavirus disease (COVID19): spectrum of $C T$ findings and temporal progression of the disease. Acade Radiol 2020;27(5):603-608. DOI: 10.1016/j.acra.2020.03.003.

13. Richman DD, Whitley RJ, Hayden FG, ed. Clinical virology. John Wiley \& Sons; 2016.

14. Lu R, Zhao X, Li J, Niu P, Yang B, Wu H, et al. Genomic characterisation and epidemiology of 2019 novel coronavirus: implications for virus origins and receptor binding. Lancet 2020;395(10224):565-574. DOI: 10.1016/S0140-6736(20)30251-8.

15. Ather A, Patel B, Ruparel NB, Diogenes A, Hargreaves KM. Coronavirus disease 19 (COVID-19): implications for clinical dental care. J Endod 2020;46(5):584-595. DOI: 10.1016/j.joen.2020.03.008.

16. World Health Organization, Summary of probable SARS cases with onset of illness from 1 November 2002 to 31 July 2003.

17. Zumla A, Hui DS, Perlman S. Middle East respiratory syndrome. Lancet 2015;386(9997):995-1007. DOI: 10.1016/S0140-6736(15)60454-8.

18. https://covid19.who.int/?gclid.

19. Movert E, Wu Y, Lambeau G, Kahn F, Touqui L, Areschoug T. Using patient pathways to accelerate the drive to ending tuberculosis. J Infect Dis 2013;208(12):2025-2035. DOI: 10.1093/infdis/jit359.

20. Chan-Yeung M, Xu RH. SARS: epidemiology. Respirology 2003;8(Suppl 1):S9-S14.

21. Xu RH, He JF, Evans MR, Peng GW, Field HE, Yu DW, et al. Epidemiologic clues to SARS origin in China. Emerg Infect Dis 2004;10(6):1030. DOI: 10.3201/eid1006.030852.

22. Mobaraki K, Ahmadzadeh J. Current epidemiological status of Middle East respiratory syndrome coronavirus in the world from 1.1.2017 to 17.1.2018: a cross-sectional study. BMC Infect Dis 2019;19(1):351. DOI: 10.1186/s12879-019-3987-2.

23. Chen N, Zhou M, Dong X, Qu J, Gong F, Han Y, et al. Epidemiological and clinical characteristics of 99 cases of 2019 novel coronavirus pneumonia in Wuhan, China: a descriptive study. Lancet 2020;395(10223):507-513. DOI: 10.1016/S0140-6736(20)30211-7.

24. Lv L, Li G, Chen J, Liang X, Li Y. Comparative genomic analysis revealed specific mutation pattern between human coronavirus SARS-CoV-2 and Bat-SARSr-CoV RaTG13. BioRxiv 2020. DOI: 10.1101/2020.03.15.993097.

25. Fan Y, Zhao K, Shi ZL, Zhou P. Bat coronaviruses in China. Viruses 2019;11(3):210. DOI: 10.3390/v11030210.

26. Kelly H, Peck HA, Laurie KL, Wu P, Nishiura H, Cowling BJ. The agespecific cumulative incidence of infection with pandemic influenza H1N1 2009 was similar in various countries prior to vaccination. PLoS ONE 2011;6(8). DOI: 10.1371/journal.pone.0021828.

27. World Health Organization (WHO). Novel coronavirus (2019-nCoV) situation report-1.2020.

28. World Health Organization (WHO). Novel coronavirus (2019-nCoV) situation report-2.2020.

29. World Health Organization (WHO). Coronavirus disease 2019 (COVID19) situation report -56.2020 .

30. https://www.who.int/docs/default-source/coronaviruse/situationreports/20200316-sitrep-56-covid19.pdf?sfvrsn=9fda7db2_6.

31. World Health Organization. Novel coronavirus_china. 2020.

32. Holshue ML, DeBolt C, Lindquist S, Lofy KH, Wiesman J, Bruce H, et al. First case of 2019 novel coronavirus in the United States. N Eng J Med 2020;382(10):929-936. DOI: 10.1056/NEJMoa2001191.
33. Chen P, Mao L, Nassis GP, Harmer P, Ainsworth BE, Li F. Wuhan coronavirus (2019-nCoV): the need to maintain regular physical activity while taking precautions. J Sport Health Sci 2020;9(2):103. DOI: 10.1016/j.jshs.2020.02.001.

34. World Health Organization. IHR procedures concerning public health emergencies of international concern (PHEIC). Geneva: World Health Organization.

35. World Health Organization (WHO). Novel coronavirus (2019-nCoV) situation report - 21. 2020.

36. World Health Organization (WHO). Rolling updates on coronavirus disease (COVID-19). 2020.

37. World Health Organization (WHO). Coronavirus disease 2019 (COVID19) situation report - 50. 2020.

38. World Health Organization (WHO). WHO Director-General's opening remarks at the media briefing on COVID-19. 2020.

39. Wei WE, Li Z, Chiew CJ, Yong SE, Toh MP, Lee VJ. Presymptomatic transmission of SARS-CoV-2-Singapore, January 23-March 16, 2020. Morbid Mortal Weekly Rep 2020;69(14):411. DOI: 10.15585/mmwr. mm6914e1.

40. Van Doremalen N, Bushmaker T, Morris DH, Holbrook MG, Gamble A, Williamson BN, et al. Aerosol and surface stability of SARS-CoV-2 as compared with SARS-CoV-1. N Eng J Med 2020;382(16):1564-1567. DOI: 10.1056/NEJMc2004973.

41. Kampf G, Todt D, Pfaender S, Steinmann E. Persistence of coronaviruses on inanimate surfaces and its inactivation with biocidal agents. J Hosp Infect 2020;104(3):246-251. DOI: 10.1016/j. jhin.2020.01.022.

42. Centers for Disease Control and Prevention. Coronavirus disease 2019: how it spreads. 2020.

43. Rothe C, Schunk M, Sothmann P, Bretzel G, Froeschl G, Wallrauch C, et al. Transmission of 2019-nCoV infection from an asymptomatic contact in Germany. N Engl J Med 2020;382(10):970-971. DOI: 10.1056/ NEJMc2001468.

44. Riccardo F, Ajelli M, Andrianou X, Bella A, Del Manso M, Fabiani $M$, et al. Epidemiological characteristics of COVID-19 cases in Italy and estimates of the reproductive numbers one month into the epidemic. medRxiv 2020;25(49):2000790. DOI: 10.2807/1560-7917. ES.2020.25.49.2000790.

45. An der Heiden $M$, Hamouda O. Schätzung der aktuellen Entwicklung der SARS-CoV-2-Epidemie in Deutschland-nowcasting. Epid Bull 2020;17:10-15.

46. Wolfel R, Corman VM, Guggemos W, Seilmaier M, Zange S, Müller MA, et al. Virological assessment of hospitalized patients with COVID-2019. Nature 2020(7809):1-5. DOI: 10.1038/s41586-020-2196-x.

47. Liu Y, Yan LM, Wan L, Xiang TX, Le A, Liu JM, et al. Viral dynamics in mild and severe cases of COVID-19. Lancet Infect Dis 2020;20(6):656-657. DOI: 10.1016/S1473-3099(20)30232-2.

48. Lavezzo E, Franchin E, Ciavarella C, Cuomo-Dannenburg G, Barzon L, Del Vecchio C, et al. Suppression of COVID-19 outbreak in the municipality of Vo, Italy. medRxiv 2020.

49. Peng L, Liu J, Xu W, Luo Q, Deng K, Lin B, et al. 2019 Novel coronavirus can be detected in urine, blood, anal swabs and oropharyngeal swabs samples. medRxiv 2020.

50. Colavita F, Lapa D, Carletti F, Lalle E, Bordi L, Marsella P, et al. SARSCoV-2 isolation from ocular secretions of a patient with COVID-19 in Italy with prolonged viral RNA detection. Ann Int Med 2020(3):M201176. DOI: 10.7326/M20-1176.

51. Aguilar JB, Faust JS, Westafer LM, Gutierrez JB. Investigating the impact of asymptomatic carriers on COVID-19 transmission. medRxiv 2020.

52. Corman VM, Rabenau HF, Adams O, Oberle D, Funk MB, KellerStanislawski B, et al. SARS-CoV-2 asymptomatic and symptomatic patients and risk for transfusion transmission. Transfusion 2020;60(6):1119-1122. DOI: 10.1111/trf.15841.

53. Chow EJ, Schwartz NG, Tobolowsky FA, Zacks RL, Huntington-Frazier $M$, Reddy SC, et al. Symptom screening at illness onset of health care personnel with SARS-CoV-2 infection in King County, Washington. JAMA 2020;323(20):2087-2089. DOI: 10.1001/jama.2020.6637. 
54. Centers for Disease Control and Prevention. Symptoms of coronavirus. Retrieved from. 2020.

55. Cui S, Chen S, Li X, Liu S, Wang F. Prevalence of venous thromboembolism in patients with severe novel coronavirus pneumonia. J Thromb Haemost 2020;18(6):1421-1424. DOI: 10.1111/ jth.14830.

56. Tang N, Li D, Wang X, Sun Z. Abnormal coagulation parameters are associated with poor prognosis in patients with novel coronavirus pneumonia. J Thromb Haemos 2020;18(4):844-847. DOI: 10.1111/ jth.14768.

57. Lippi G, Favaloro EJ. D-dimer is associated with severity of coronavirus disease 2019: a pooled analysis. Thromb Haemos 2020;120(05):876878. DOI: 10.1055/s-0040-1709650.

58. Wang D, Hu B, Hu C, Zhu F, Liu X, Zhang J, et al. Clinical characteristics of 138 hospitalized patients with 2019 novel coronavirus-infected pneumonia in Wuhan, China. JAMA 2020;323(11):1061-1069. DOI: 10.1001/jama.2020.1585.

59. FIND. SARS-COV-2 diagnostic pipeline. 2020 (https://www.finddx. org/covid-19/pipeline/).

60. Babiker A, Myers CW, Hill CE, Guarner J. SARS-CoV-2 testing: trials and tribulations. Am J Clin Pathol 2020;153(6):706-708. DOI: 10.1093/ajcp/ aqaa052.

61. Han H, Luo Q, Mo F, Long L, Zheng W. SARS-CoV-2 RNA more readily detected in induced sputum than in throat swabs of convalescent COVID-19 patients. Lancet Infect Dis 2020;20(6):655-656. DOI: 10.1016/S1473-3099(20)30174-2.

62. Yang Y, Yang M, Shen C, Wang F, Yuan J, Li J, et al. Laboratory diagnosis and monitoring the viral shedding of 2019-nCoV infections. MedRxiv 2020.

63. Centers for Disease Control. Pevention. Interim Guidelines for Collecting, Handling, and Testing Clinical Specimens from Persons for Coronavirus Disease 2019 (COVID-19).

64. Food and Drug Administration. FAQs on diagnostic testing for SARSCoV-2. 2020.

65. Huang C, Wang Y, Li X, Ren L, Zhao J, Hu Y, et al. Clinical features of patients infected with 2019 novel coronavirus in Wuhan, China. Lancet 2020;395(10223):497-506. DOI: 10.1016/S0140-6736(20) 30183-5.

66. Wu C, Chen X, Cai Y, Zhou X, Xu S, Huang H, et al. Risk factors associated with acute respiratory distress syndrome and death in patients with coronavirus disease 2019 pneumonia in Wuhan, China. JAMA Int Med 2020;180(7):934-943. DOI: 10.1001/jamainternmed.2020.0994.

67. Wu Z, McGoogan JM. Characteristics of and important lessons from the coronavirus disease 2019 (COVID-19) outbreak in China: summary of a report of 72314 cases from the Chinese center for disease control and prevention. JAMA 2020;323(13):1239-1242. DOI: 10.1001/ jama.2020.2648.

68. Zhou F, Yu T, Du R, Fan G, Liu Y, Liu Z, et al. Clinical course and risk factors for mortality of adult inpatients with COVID-19 in Wuhan, China: a retrospective cohort study. Lancet 2020;395(10229):10541062. DOI: 10.1016/S0140-6736(20)30566-3.

69. Centers for Disease Control and Prevention. Interim guidance for implementing home care of people not requiring hospitalization for coronavirus disease 2019 (COVID-19). 2020.

70. Liu J, Cao R, Xu M, Wang X, Zhang H, Hu H, et al. Hydroxychloroquine, a less toxic derivative of chloroquine, is effective in inhibiting
SARS-CoV-2 infection in vitro. Cell Discov 2020;6(1):1-4. DOI: 10.1038/ s41421-019-0132-8.

71. Wang M, Cao R, Zhang L, Yang X, Liu J, Xu M, et al. Remdesivir and chloroquine effectively inhibit the recently emerged novel coronavirus (2019-nCoV) in vitro. Cell Res 2020;30(3):269-271. DOI: 10.1038/s41422-020-0282-0.

72. Sheahan TP, Sims AC, Graham RL, Menachery VD, Gralinski LE, Case $J B$, et al. Broad-spectrum antiviral GS-5734 inhibits both epidemic and zoonotic coronaviruses. Sci Translat Med 2017;9(396):eaal3653. DOI: 10.1126/scitransImed.aal3653.

73. Sheahan TP, Sims AC, Leist SR, Schafer A, Won J, Brown AJ, et al. Comparative therapeutic efficacy of remdesivir and combination lopinavir, ritonavir, and interferon beta against MERS-CoV. Nat Commun 2020;11(1):1-4. DOI: 10.1038/s41467-019-13940-6.

74. De Wit E, Feldmann F, Cronin J, Jordan R, Okumura A, Thomas T, et al. Prophylactic and therapeutic remdesivir (GS-5734) treatment in the rhesus macaque model of MERS-CoV infection. Proceed Nat Acad Sci 2020;117(12):6771-6776. DOI: 10.1073/pnas.1922083117.

75. Giannis D, Ziogas IA, Gianni P. Coagulation disorders in coronavirus infected patients: COVID-19, SARS-CoV-1, MERS-CoV and lessons from the past. J Clin Virol 2020. 104362. DOI: 10.1016/j.jcv.2020. 104362.

76. Fang L, Karakiulakis G, Roth M. Are patients with hypertension and diabetes mellitus at increased risk for COVID-19 infection? Lancet Respirat Med 2020;8(4):e21. DOI: 10.1016/S2213-2600(20)30116-8.

77. Zheng Y-Y, Ma Y-T, Zhang J-Y, Xie X. COVID-19 and the cardiovascular system. Nat Rev Cardiol 2020;17(5):259-260. DOI: 10.1038/s41569-0200360-5.

78. World Health Organization, Coronavirus disease (COVID-19) technical guidance: infection prevention and control. 2020.

79. Public Health England. COVID-19: infection prevention and control (IPC). 2020.

80. Government of Canada. Personal protective equipment against COVID-19. 2020.

81. Australian Government Department of Health. Interim recommendations for the use of personal protective equipment (PPE) during hospital care of people with Coronavirus Disease 2019 (COVID-19). 2020.

82. Centers for Disease Control and Prevention. Who needs PPE. 2020 (https://www.cdc.gov/coronavirus/2019-ncov/hcp/using-ppe.html).

83. Mizumoto K, Kagaya K, Zarebski A, Chowell G. Estimating the asymptomatic proportion of coronavirus disease 2019 (COVID-19) cases on board the diamond princess cruise ship, Yokohama, Japan, 2020. Euro Surveill 2020. ; 25(10):2000180. DOI: 10.2807/1560-7917. ES.2020.25.10.2000180.

84. Zhang J, Tian S, Lou J, Chen Y. Familial cluster of COVID-19 infection from an asymptomatic. Crit Care 2020;24(1):1-3. DOI: 10.1186/s13054020-2817-7.

85. Bai Y, Yao L, Wei T, Tian F, Jin DY, Chen L, et al. Presumed asymptomatic carrier transmission of COVID-19. JAMA 2020;323(14):1406-1407. DOI: 10.1001/jama.2020.2565.

86. Klompas M, Morris CA, Sinclair J, Pearson M, Shenoy ES. Universal masking in hospitals in the Covid-19 era. N Engl J Med 2020;383(2):e9. DOI: 10.1056/NEJMc2020836.

87. CHAPTER I. The Indian Medical Council (Professional Conduct, Etiquette and Ethics) Regulations, 2002. Issues Med Ethics 2002;10:3. 